\title{
Broadening the Gas Separation Utility of Monolayer Nanoporous Graphene Membranes by An Ionic Liquid Gating
}

Wei Guo, +, Shannon M. Mahurin, ' Raymond R. Unocic, ${ }^{\S}$ Huimin Luo, " and Sheng Dai, $*+,+$

${ }^{\dagger}$ Chemical Sciences Division, Oak Ridge National Laboratory, Oak Ridge, Tennessee 37831, United States. Email: dais@ornl.gov

tDepartment of Chemistry, The University of Tennessee, Knoxville, 37996 United States.

${ }^{\S}$ Center for Nanophase Materials Sciences, Oak Ridge National Laboratory, Oak Ridge, Tennessee 37831, United States.

"Energy and Transportation Science Division, Oak Ridge National Laboratory, Oak Ridge, Tennessee 37831, United States. 


\section{Methods}

CVD synthesis of graphene. The single-crystal graphene was grown on $\mathrm{Cu}$ via an ambient pressure CVD method. First, a $0.035 \mathrm{~mm}$ thick $\mathrm{Cu}$ foil (Nimrod Copper Co.) was electropolished in concentrated $\mathrm{H}_{3} \mathrm{PO}_{4}(85 \%$, Alfa Aesar) at $1.5 \mathrm{~V}$ for 20 min, followed by rinsing with deionized water and drying in a $\mathrm{N}_{2}$ stream. The clean $\mathrm{Cu}$ foil was then loaded into a 1 inch quartz tube in the middle of the heating zone of a tube furnace and heated to $1070{ }^{\circ} \mathrm{C}$ in $240 \mathrm{sccm}$ Ar within $30 \mathrm{~min}$. A mix of $50 \mathrm{sccm} \mathrm{CH} 4$ ( $0.1 \%$ diluted in $\mathrm{Ar}$ ) and $20 \mathrm{sccm} \mathrm{H}_{2}$ was subsequently introduced in the chamber for 180 min for graphene growth. A moisture trap and an oxygen trap were added in the gas line to diminish any $\mathrm{H}_{2} \mathrm{O}$ and $\mathrm{O}_{2}$ impurities as much as possible for reproducible large single-crystal graphene growth. ${ }^{[1]}$

CVD synthesis of CNT web. The CNT web was synthesized by a floating catalyst method based on ferrocene vapor decomposition in an organic solvent vapor atmosphere. ${ }^{[2]}$ The precursor solutions $\left(0.045 \mathrm{~g} \mathrm{ml}^{-1}\right.$ ferrocene and $0.001 \mathrm{~g} \mathrm{ml}^{-1}$ sulfur dissolved in $1 \mathrm{ml}$ xylene, Sigma Aldrich) were confined in a closed small vial with a pinhole and put in a low-temperature zone at the upstream section of the quartz tube (Figure S2). The chamber was first heated to $1160{ }^{\circ} \mathrm{C}$ in $40 \mathrm{sccm}$ Ar. Then a mix of high-flux $\mathrm{H}_{2}(150 \mathrm{sccm})$ and $\mathrm{Ar}(850 \mathrm{sccm})$ was introduced into the chamber for the CNTs growth for 60-120 min. A scrolled copper foil and a polymer filter were placed downstream to collect the CNTs. 
CNT web supported graphene membrane fabrication. The as-grown CNT webs, collected on a $\mathrm{Cu}$ foil or polymer filter, can be easily transferred onto graphene film by a room-temperature dry-press transfer technique. ${ }^{[3]}$ The CNT-web can conformally contact with graphene film by mild hand pressure. After that, the collection substrate can be removed by lifting. Then the CNT-web is attached onto graphene. This process is faster and cleaner than conventional PMMA supported transfer method. The CNT web/graphene membrane was soaked in ethanol where CNTs formed bundles and collapsed into a web, then dried in air to form a sturdy cross-linked CNT web support. Finally, the CNT web/graphene membrane was then isolated from the $\mathrm{Cu}$ substrate by wet chemical etching with $\mathrm{NH}_{4} \mathrm{~S}_{2} \mathrm{O}_{8}$ solution (98\%, Sigma Aldrich), followed by water rinsing and drying in air. The CNT web/graphene membrane was finally transferred onto porous substrates of $\mathrm{Cu}$ grids, holey tungsten foils and holey PDMS support. The holey tungsten substrate was prepared by drilling a sub-nanometer sized hole by small drill bits with diameter of $150-300 \mu \mathrm{m}$.

IL/NPG membrane fabrication. The nanopores were introduced into the CNT web supported graphene membrane using an oxygen plasma etcher (Diener) operating at 15 $\mathrm{W}$ and with the $\mathrm{O}_{2}$ flow rate of $20 \mathrm{ml} \mathrm{min}^{-1}$. The exposure time was controlled from $\sim 0.5 \mathrm{~s}$ to $3 \mathrm{~s}$ for tuning the pore size and density. After perforation, a layer of the ILs was placed onto the nanoporous graphene by drop-coating the ethanoic IL solution with concentrations from $0.001 \mathrm{wt} \%$ to $5 \mathrm{wt} \%$. The ILs used in this work $\left(\mathrm{BmimTf}_{2} \mathrm{~N}\right.$, $\mathrm{BmimBF}_{4}$ and $\left.\operatorname{EmimB}(\mathrm{CN})_{4}\right)$ were purchased from Io-li-tec. 
Gas transport test. Pure gas transport test was carried out at a temperature of $22{ }^{\circ} \mathrm{C}$ and feed pressure of $45 \mathrm{kpa}$, using a custom constant-volume pressure-increase apparatus. The membrane sample was mounted on a 50-um-thick tungsten foil with a hole at the center. The hole was created by a drill bit with a diameter of $0.3 \mathrm{~mm}$ or a power punch with a diameter of $2 \mathrm{~mm}$. The sample was sandwiched and sealed between the Swagelok VCR fittings. The pressure rise was monitored using a 10-Torr Baratron gauge. From the slope of this pressure rise, the permeability was calculated based on the equation:

$$
P=\frac{V l}{R T A(\Delta p)} \frac{d p}{d t}
$$

where $\mathrm{V}$ is the permeate volume, 1 tis the membrane thickness, $\mathrm{R}$ is the gas constant, $\mathrm{T}$ is the absolute temperature, $\mathrm{A}$ is the membrane area, $\Delta \mathrm{p}$ is the pressure difference across the membrane and $\mathrm{dp} / \mathrm{dt}$ is the rate of gas pressure increase on the permeate side.

Characterization. The microscopy characterizations were conducted using a SEM (JEOL JSM-6050) at $1 \mathrm{kV}$. High-resolution images were acquired by Hitachi-2000 scanning tunneling electron microscopy (STEM) operating at $200 \mathrm{kV}$. Raman spectroscopy was performed by a Renishaw In-Via Raman spectrum instrument with emission laser wave length of $532 \mathrm{~nm}$. 


\section{Note 1. Single-crystal graphene synthesis}

Large-area single-crystal graphene can be synthesized via an oxygen-free CVD approach at atmospheric pressure. ${ }^{[1]}$ A grain boundary-free graphene film can be obtained for fabricating mechanically sturdy graphene membranes.

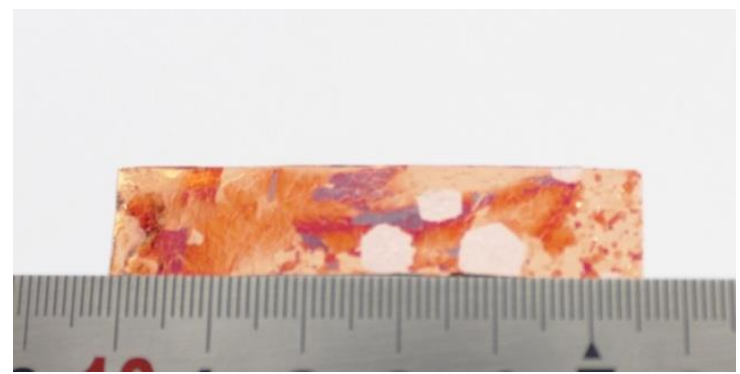

Figure S1. Photograph of single-crystal graphene grains in dimension up to $6 \mathrm{~mm}$ on $\mathrm{Cu}$ substrate.

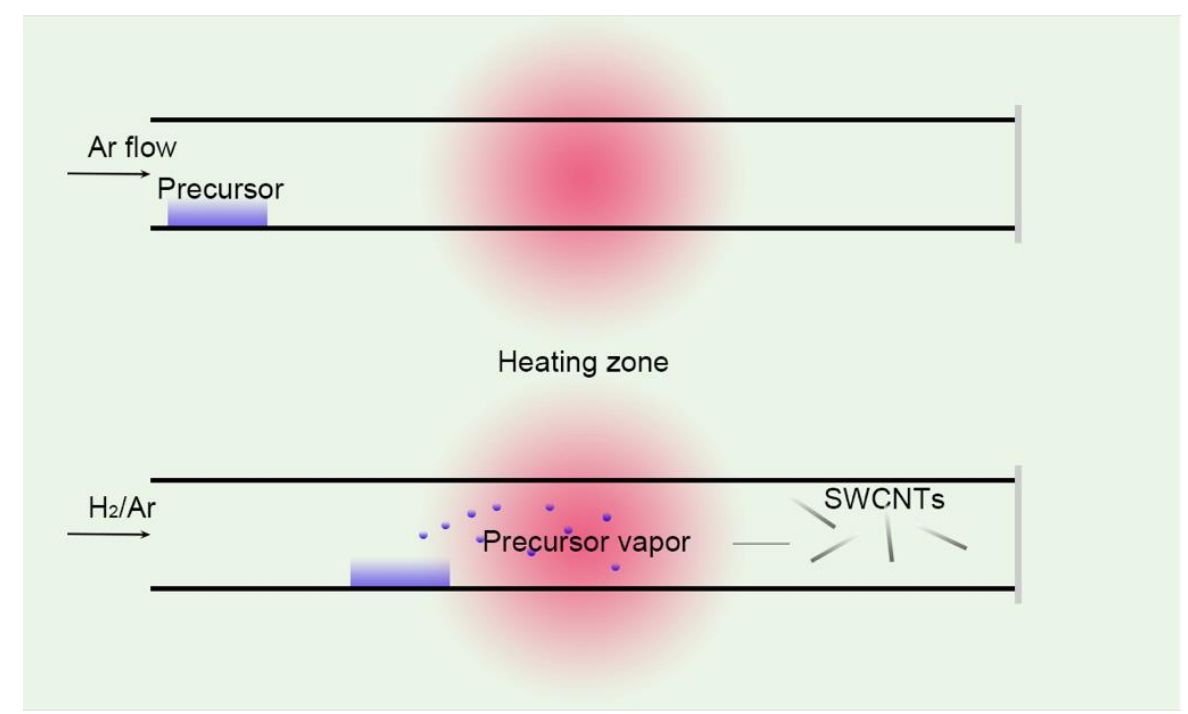

Figure S2. Schematic showing of the CVD setup for CNT web synthesis. 


\section{Note 2. Role of CNT web support}

CNT webs with various thicknesses were synthesized via a standard CVD process (Figure S2), and directly pressed onto the graphene surface (Figure S3). The grapheneon-CNT web substrate presents an imprint of the $\mathrm{Cu}$ surface morphology (Figure S4).

Because the fluffy texture of the CNT web can perfectly match the microscopically uneven surface of the solid $\mathrm{Cu}$ substrate, the graphene is well preserved and remains intact during the transfer procedure.

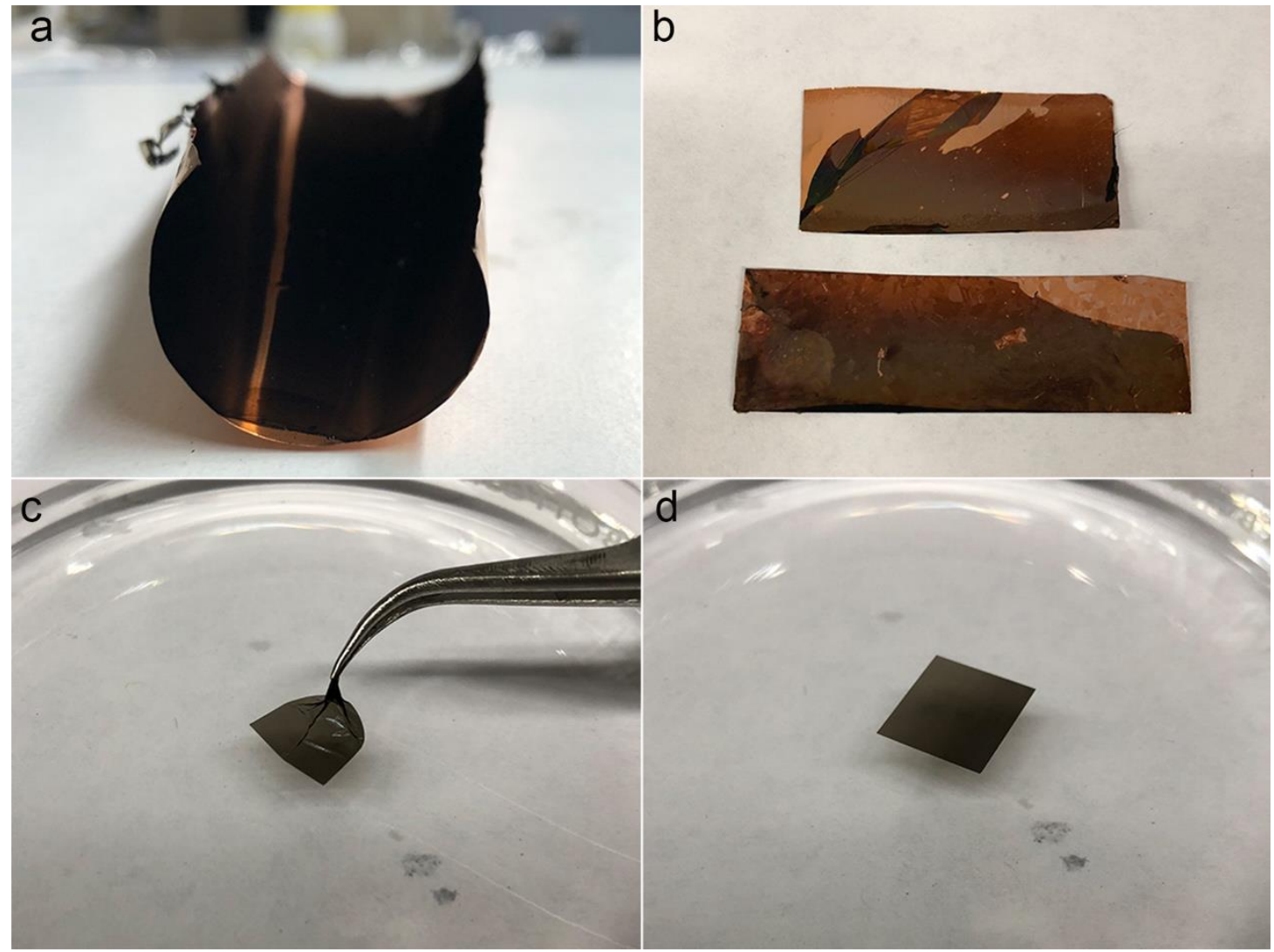

Figure S3. (a) The CVD grown CNT web collected on $\mathrm{Cu}$ foil. (b) The CNT web was pressed onto the graphene/Cu. (c, d) The CNT web/graphene membrane delaminated from $\mathrm{Cu}$ was floated on water. It can be lifted from water and then suspended in water. 


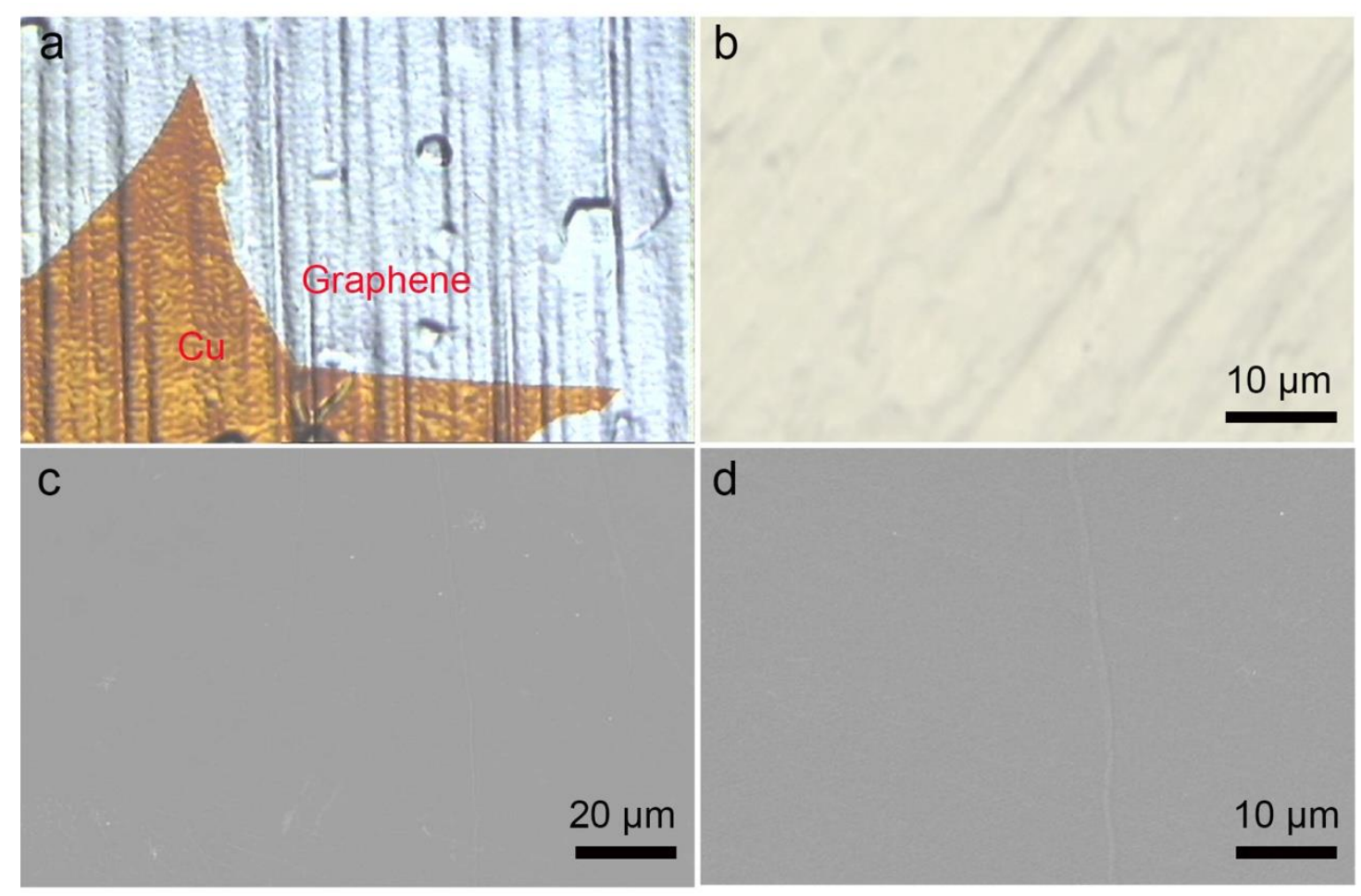

Figure S4. (a) The optical microscopy image of the morphology of the $\mathrm{Cu}$ substrate with as-grown graphene covering the surface. (b) The morphology of graphene film supported by the $\mathrm{CNT}$ web substrate after eliminating the $\mathrm{Cu}$ substrate by chemical etching with $\left(\mathrm{NH}_{4}\right)_{2} \mathrm{~S}_{2} \mathrm{O}_{8}$. The uneven graphene film shows an imprint of the surface morphology of the $\mathrm{Cu}$ substrate. (c, d) The SEM images of graphene supported on a CNT web. 


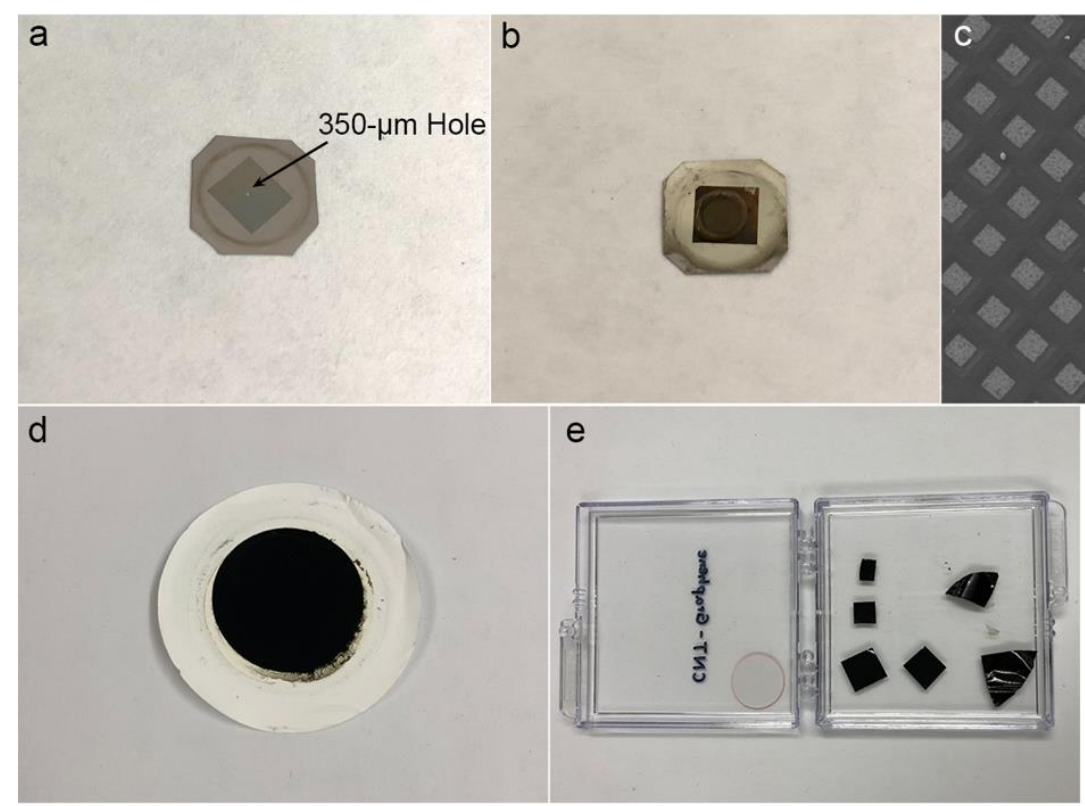

Figure S5. (a) A suspended CNT/graphene membrane on a tungsten foil with a 350$\mu \mathrm{m}$-diameter hole in the middle. (b, c) An intact large-area CNT/graphene membrane transferred onto a commercial $\mathrm{Cu}$ grid with $80 \times 80 \mu \mathrm{m}^{2}$ holes. (d) An as-grown thick CNT web support membrane collected on a 47-mm diameter polymer filter with pore size of $800 \mathrm{~nm}$. (e) The free-standing CNT/graphene membranes (black) with thickness of $1-2 \mu \mathrm{m}$. 

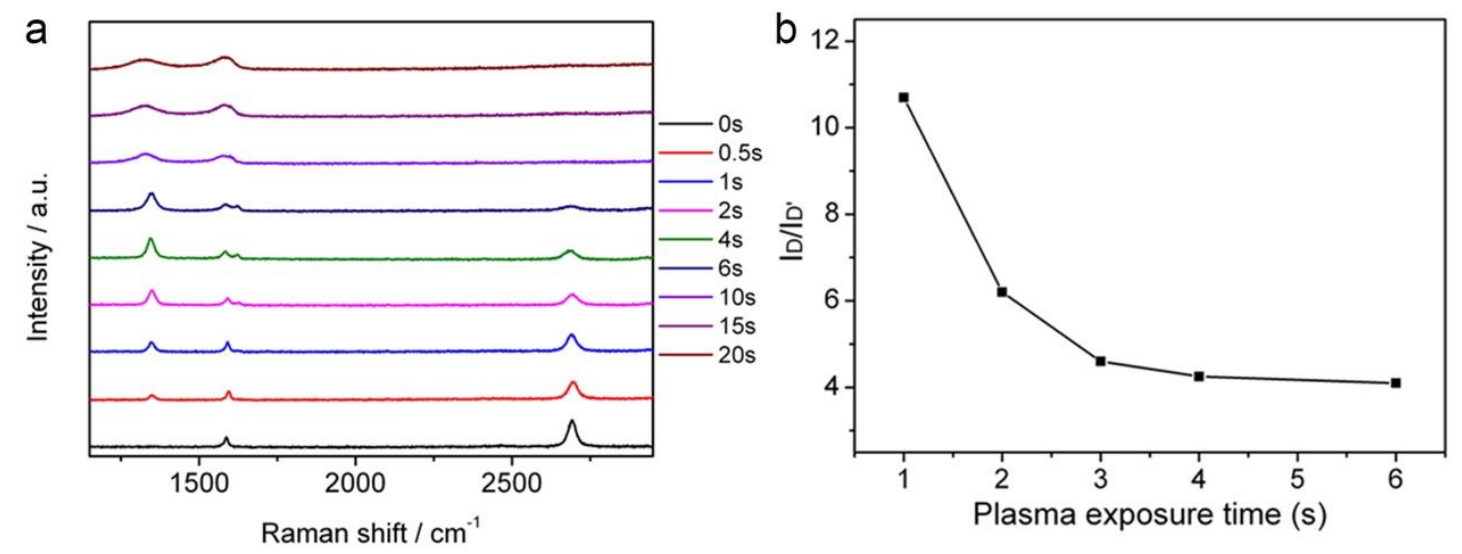

Figure S6. (a) Raman spectra of graphene after exposure to $\mathrm{O}_{2}$ plasma for different etching times ranging from 0 to $20 \mathrm{~s}$. (b) $\mathrm{ID}_{\mathrm{D}} / \mathrm{ID}_{\mathrm{D}}$ ' as a function of plasma exposure time. The $\mathrm{ID}_{\mathrm{D}} \mathrm{ID}_{\mathrm{D}}$ ratio is 10.8 after $1 \mathrm{~s}$ plasma exposure, then decreased to 6.1 after $2 \mathrm{~s}$ and further decreased to $\sim 4$ after $6 \mathrm{~s}$. Because the $\mathrm{ID}_{\mathrm{D}} / \mathrm{I}_{\mathrm{D}}$ ' ratio can be used to distinguish predominantly $\mathrm{sp}^{3}$-type defect $\left(\mathrm{ID}_{\mathrm{D}} / \mathrm{ID}^{\prime}>7\right)$ and predominantly vacancy-type defects $\left(\mathrm{ID}_{\mathrm{D}} / \mathrm{ID}^{\prime}<7\right)$. Long plasma etching (> $6 \mathrm{~s}$ ) leads to more vacancies but larger pore sizes.

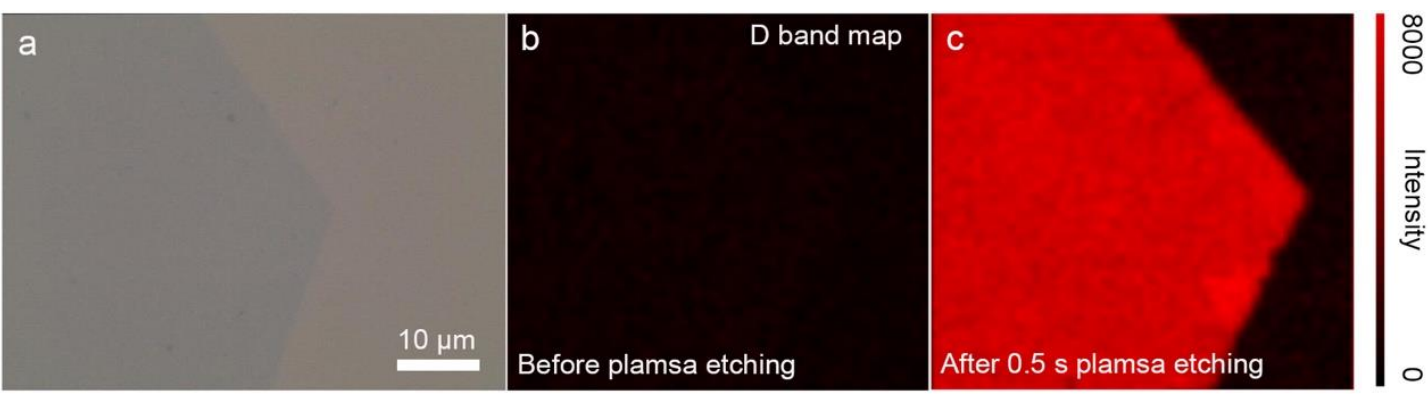

Figure S7. Raman mapping of the D band $\left(\sim 1350 \mathrm{~cm}^{-1}\right)$ at a corner of a hexagonal single-crystal graphene grain before and after $\mathrm{O}_{2}$ plasma etching. The region of graphene for the mapping measurement is identical after plasma treatment. The homogeneous D band mapping confirmed the uniform etching all over the graphene film. 


\section{Note 3. Estimation porosity in nanoporous graphene by Raman spectra}

The evolution of the defect-density in nanoporous graphene with the plasma exposure time can be estimated by analyzing the ratio of $D$ band and $G$ band, $I_{D} / I_{G}$, from the Raman spectra. This ratio depends on the defect density, type of defects and the size of etched nanopores. For the pristine graphene with rare defects, $I_{D} / I_{G}$ is proportional to the total number of defects probed by the Raman laser spot. The defect density at different stages can be estimated using the empirical equation: ${ }^{[4,5]}$

$$
L_{D}^{2}\left(n m^{2}\right)=\frac{4.3 \times 10^{3}}{E_{l}^{4}}\left[\frac{I_{D}}{I_{G}}\right]^{-1}
$$

Where $\mathrm{LD}_{\mathrm{D}}$ is the average distance between defects, $\mathrm{E}_{1}$ is the excitation energy in $\mathrm{eV}$ which is $2.33 \mathrm{eV}$ for $532 \mathrm{~nm}$ wavelength laser.

The etching process can be divided into two regimes: low defect density regime and high defect density regime. In the former regime, the $\mathrm{I}_{\mathrm{D}} / \mathrm{I}_{\mathrm{G}}$ increases with plasma exposure time, reflecting the growing number of defects. In the latter stage, the $\mathrm{I}_{\mathrm{D}} / \mathrm{IG}_{\mathrm{G}}$ decreases with exposure time, which is attributed to reducing the number of ordered $\mathrm{sp}^{2}$ carbons and emerging $\mathrm{sp}^{3}$ disordered carbons. We observed that the $\mathrm{ID}_{\mathrm{D}} / \mathrm{I}_{\mathrm{G}}$ reached a maximum value of $\sim 2$ with plasma exposure time of $3 \mathrm{~s}$. Thus we can estimate the defect density (number of defect per unit area, $n_{D}, \mathrm{~cm}^{-2}$ ) with plasma etching with $2 \mathrm{~s}$, which lies in the low-defect-density regime, using the equation below:

$$
n_{D}\left(\mathrm{~cm}^{-2}\right)=\frac{10^{14}}{\pi L_{D}^{2}}
$$




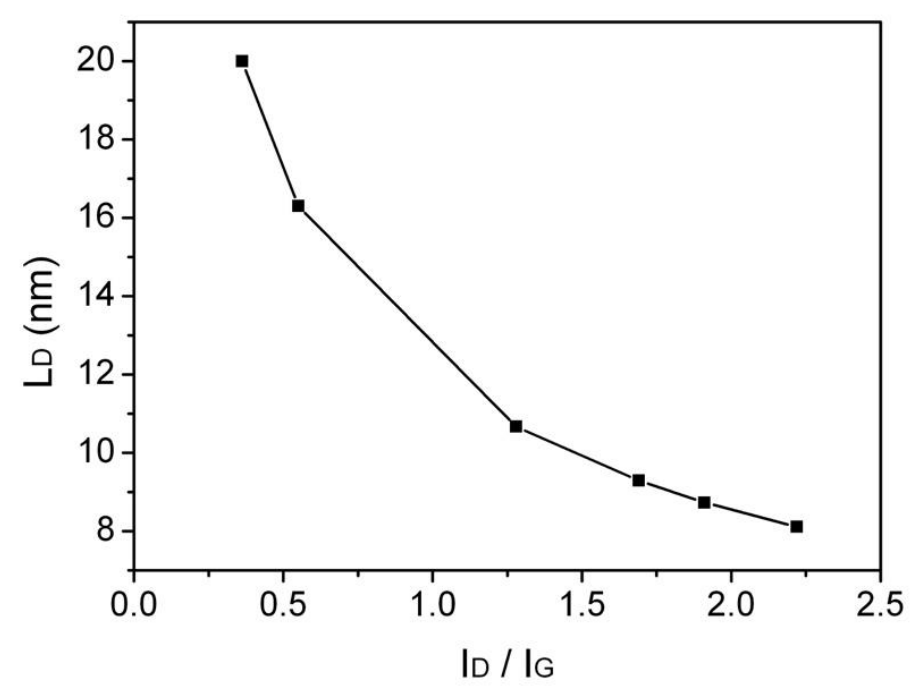

Figure S8. The porosity of nanoporous graphene with respect to the defect density of $\mathrm{ID} / \mathrm{IG}_{\mathrm{G}}$

a<smiles>CCCCn1ccnc1</smiles>

1-Butyl-3-methylimidazolium tetrafluoroborate

$\mathrm{BmimBF}_{4}$<smiles></smiles>

1-Butyl-3-methylimidazolium bis(trifluoromethylsulfonyl)imide $\mathrm{Bmim} \mathrm{Tf}_{2} \mathrm{~N}$

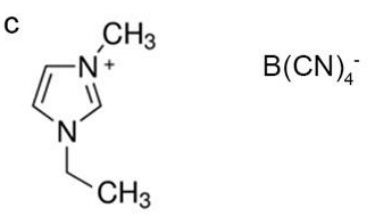

1-Ethyl-3-methylimidazolium tetracyanoborate

$\operatorname{EmimB}(\mathrm{CN})_{4}$

Figure S9. The structure of the ILs used for hybrid NPG membranes. 

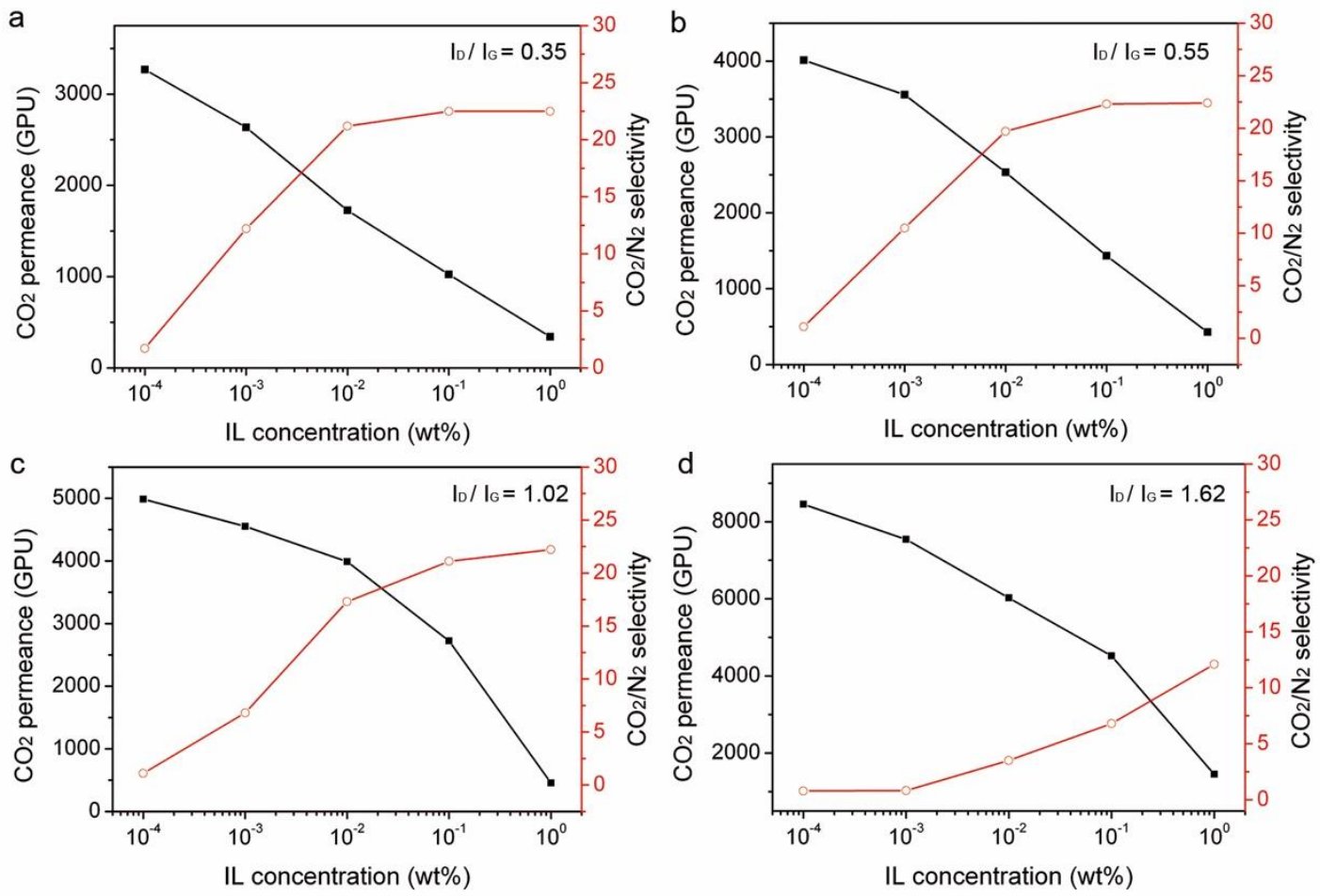

Figure S10. The $\mathrm{CO}_{2}$ permeance and $\mathrm{CO}_{2} / \mathrm{N}_{2}$ selectivity as a function of the IL concentration of NPG membranes with different defect density. 
Table S1. Summary of the $\mathrm{CO}_{2}$ permeance, $\mathrm{CO}_{2} / \mathrm{N}_{2}$ selectivity of NPG membranes with different defect density and various concentrations of $\mathrm{BmimBF}_{4} \mathrm{IL}$.

\begin{tabular}{|c|c|c|c|}
\hline Defect density $\left(I_{D} / I_{G}\right)$ & $\begin{array}{l}\text { IL concentration in } \\
\text { ethanol } \\
\text { [wt\%] }\end{array}$ & $\begin{array}{l}\mathrm{CO}_{2} \text { permeance } \\
{[\mathrm{GPU}]}\end{array}$ & $\mathrm{CO}_{2} / \mathrm{N}_{2}$ selectivity \\
\hline 0.35 & 0.0001 & 3268 & 1.7 \\
\hline 0.35 & 0.001 & 2634 & 12.2 \\
\hline 0.35 & 0.01 & 1726 & 21.2 \\
\hline 0.35 & 0.1 & 1025 & 22.5 \\
\hline 0.35 & 1 & 342 & 22.5 \\
\hline 0.55 & 0.0001 & 4012 & 1.1 \\
\hline 0.55 & 0.001 & 3557 & 10.5 \\
\hline 0.55 & 0.01 & 2535 & 19.7 \\
\hline 0.55 & 0.1 & 1434 & 22.3 \\
\hline 0.55 & 1 & 428 & 22.4 \\
\hline 1.02 & 0.0001 & 4987 & 1.1 \\
\hline 1.02 & 0.001 & 4554 & 6.8 \\
\hline 1.02 & 0.01 & 3991 & 17.3 \\
\hline 1.02 & 0.1 & 2724 & 21.1 \\
\hline 1.02 & 1 & 457 & 22.2 \\
\hline 1.61 & 0.0001 & 8454 & 0.79 \\
\hline 1.61 & 0.001 & 7543 & 0.81 \\
\hline 1.61 & 0.01 & 6026 & 3.5 \\
\hline 1.61 & 0.1 & 4521 & 6.8 \\
\hline 1.61 & 1 & 1451 & 12.1 \\
\hline
\end{tabular}




\section{Note 4. Estimating the thickness of ultrathin IL layer}

It is not easy to acquire the exact thickness or number of layers of ILs. We can roughly estimate that according to the amount of the ILs loaded on graphene by thermogravimetric analysis (TGA). We drop coated $2-\mu \mathrm{L}$ of ethanoic $\mathrm{BmimBF}_{4} \mathrm{IL}$ solutions with concentration of $5 \mathrm{wt} \%$ on a $25 \mathrm{~mm}^{2}$ supported graphene membrane. The mass of ILs are shown in Table S2. Assuming that the ILs form an uniform layer on graphene, the thickness can be presumably calculated by IL volume and spread area. The density of $\mathrm{BmimBF}_{4} \mathrm{IL}$ is $1.21 \mathrm{mg} / \mathrm{ml}$. The thickness of $5 \mathrm{wt} \%$ of ILs on graphene is estimated to be $200 \mu \mathrm{m}$. Therefore, the thickness is estimated to be $\sim 2 \mu \mathrm{m}$ for the loading amount of $0.05 \mathrm{wt} \%$ and $400 \mathrm{~nm}$ for the loading amount of $0.01 \mathrm{wt} \%$, which is ultrathin. However, it is noted that the IL layer could not be perfect uniform on graphene. In this case, the thickness of ultrathin layer of ILs is not able to be confirmed.

Table S2. The thickness estimation of IL layer by TGA

\begin{tabular}{ccccc}
\hline $\begin{array}{c}\text { IL } \\
\text { concentration }\end{array}$ & $\begin{array}{c}\text { Total sample } \\
\text { mass }\end{array}$ & $\begin{array}{c}\text { IL Weight } \\
\text { percent } \\
{[\mathrm{wt} \%]}\end{array}$ & $\begin{array}{c}\text { IL volume } \\
{[\mathrm{mg}]}\end{array}$ & $\begin{array}{c}\text { Thickness } \\
{[\mathrm{m} \%]}\end{array}$ \\
\hline 5 & 1.37 & 0.45 & 0.005 & 200 \\
5 & 2.56 & 0.3 & 0.006 & 240 \\
\hline
\end{tabular}


Table $\mathrm{S} 3 . \mathrm{CO}_{2} / \mathrm{N}_{2}$ separation performance of IL/NPG membranes using $\mathrm{BmimTf}_{2} \mathrm{~N}$ and $\operatorname{EmimB}(\mathrm{CN})_{4}$ ILs.

\begin{tabular}{lll}
\hline Membrane type & $\mathrm{CO}_{2}$ permeance & $\mathrm{CO}_{2} / \mathrm{N}_{2}$ selectivity \\
& {$[\mathrm{GPU}]$} & \\
\hline BmimTf 2 N/NPG & 2010 & 20.4 \\
& 3330 & 18 \\
EmimB(CN) 4 /NPG & 4010 & 27 \\
& 2320 & 30.2 \\
& 1542 & 32.3 \\
\hline
\end{tabular}




\section{Note 5. Mixed gas transport test and high-temperature stability}

The selectivity of IL/NPG still kept nearly constant value at elevated temperature of 50 ${ }^{\circ} \mathrm{C}$, indicating reasonable stability at high temperature. The permeance is lower due to a thicker CNT support. The decreased selectivity is probable due to the increased $\mathrm{N}_{2}$ permeance. The mix gas (50/50) $\mathrm{CO}_{2} / \mathrm{N}_{2}$ showed a reasonable decreased selectivity, which indicated the competition between $\mathrm{CO}_{2}$ and $\mathrm{N}_{2}$ adsorption and diffusion in IL/NPG membranes.

Table S4. Comparison $\mathrm{CO}_{2} / \mathrm{N}_{2}$ separation performance from mixed gas transport measurement and as well as high temperature measurement.

\begin{tabular}{llll}
\hline & Single gas & High temperature & Mix gas \\
\hline $\mathrm{CO}_{2}$ permeance & 916 & 968 & 912 \\
[GPU] & & & \\
$\mathrm{N}_{2}$ permeance & 51 & 69 & 83 \\
{$[\mathrm{GPU}]$} & & & \\
$\mathrm{CO}_{2} / \mathrm{N}_{2}$ selectivity & 18 & 14 & 11 \\
\hline
\end{tabular}


Table S5. Comparison of $\mathrm{CO}_{2} / \mathrm{N}_{2}$ separation performance of the IL/NPG membranes with other typical polymer, MOF and graphene based hybrid membranes.

\begin{tabular}{|c|c|c|c|}
\hline Membrane type & $\begin{array}{l}\mathrm{CO}_{2} \text { permeance } \\
{[\mathrm{GPU}]}\end{array}$ & $\mathrm{CO}_{2} / \mathrm{N}_{2}$ selectivity & Reference \\
\hline Graphene oxide (GO) & 110 & 52 & 6 \\
\hline $\mathrm{BmimBF}_{4} / \mathrm{GO}$ & 68.5 & 382 & 7 \\
\hline Polymer hollow fiber/GO & 1020 & 680 & 8 \\
\hline Borate/GO & 650 & 57 & 9 \\
\hline Enzymatic solution & 2600 & 788 & 10 \\
\hline PEI/SPONPG & 5540 & 25.2 & 11 \\
\hline PEGBA/SPONPG & 4250 & 20.8 & 11 \\
\hline Cellulose acetate & 110 & 30 & 12 \\
\hline Thermally-reduced (TR) polymer & 1938 & 13 & 13 \\
\hline TR polymer/GO & 1784 & 17.7 & 14 \\
\hline TZPIMs & $\begin{array}{l}2500 \text { (assuming a } 1 \\
\text { um thickness) }\end{array}$ & 30 & 15 \\
\hline Polaris $^{\mathrm{TM}}$ & 1000 & 50 & 16 \\
\hline $\begin{array}{l}\text { Metal induced ordered micro } \\
\text { polymers (MMPs) }\end{array}$ & 3000 & 78 & 17 \\
\hline PEG/NH2-MIL-53 & 3000 & 34 & 18 \\
\hline Uio-66- $\mathrm{NH}_{2}$ in PEBAX & 338 & 57 & 19 \\
\hline \multirow[t]{2}{*}{$\mathrm{BmimBF}_{4} / \mathrm{NPG}$} & 2724 & 21.1 & \\
\hline & 3991 & 17.3 & \\
\hline \multirow[t]{2}{*}{$\mathrm{BmimTf}_{2} \mathrm{~N} / \mathrm{NPG}$} & 2010 & 20.4 & \\
\hline & 3330 & 18 & This work \\
\hline \multirow[t]{3}{*}{$\operatorname{EmimB}(\mathrm{CN})_{4} / \mathrm{NPG}$} & 4010 & 27 & \\
\hline & 2320 & 30.2 & \\
\hline & 1542 & 32.3 & \\
\hline
\end{tabular}


Table S6. The pros and cons of this membrane compared with the reported nanoporous graphene membranes in terms of fabrication and separation performance.

\begin{tabular}{|c|c|c|c|c|}
\hline & Pros & Cons & $\begin{array}{l}\text { Separation } \\
\text { performance }\end{array}$ & Reference \\
\hline IL/NPG membrane & $\begin{array}{l}\text { CNT web } \\
\text { support is more } \\
\text { sturdy in large } \\
\text { area, which can } \\
\text { suspend on } \\
\text { commonly used } \\
\text { holey support. }\end{array}$ & $\begin{array}{l}\text { Pore density is } \\
\text { limited by brief } \\
\mathrm{O}_{2} \text { plasma } \\
\text { etching }\end{array}$ & $\begin{array}{l}\mathrm{High} \mathrm{CO}_{2} \\
\text { permeance } \\
\text { of } 4000 \\
\text { GPU and } \\
\text { selectivity of } \\
32 \text {. }\end{array}$ & This work \\
\hline $\begin{array}{l}\text { Microporous } \\
\text { carbon/NPG } \\
\text { membrane }\end{array}$ & $\begin{array}{l}\text { Pore size can } \\
\text { be controlled at } \\
\text { angstrom level } \\
\text { by ozone } \\
\text { etching. }\end{array}$ & $\begin{array}{l}\text { It needs } \\
\text { additional } \\
\text { thermal } \\
\text { treatment } \\
\text { procedure for } \\
\text { applying } \\
\text { microporous } \\
\text { carbon support, } \\
\text { which is also not } \\
\text { sturdy enough at } \\
\text { large-area. }\end{array}$ & & 21 \\
\hline $\begin{array}{l}\text { PTMSP/Polymer/NPG } \\
\text { membrane }\end{array}$ & $\begin{array}{l}\text { Higher } \\
\text { selectivity can } \\
\text { be achieved by } \\
\text { high- } \\
\text { performance } \\
\text { polymers. }\end{array}$ & $\begin{array}{l}\text { It needs } \\
\text { expensive high- } \\
\text { precision } \\
\text { fabricated } \\
\text { microporous } \\
\text { tungsten foil } \\
\text { support. }\end{array}$ & $\begin{array}{l}\text { Higher } \mathrm{CO}_{2} \\
\text { permeance } \\
\text { over } 10000 \\
\text { GPU and } \\
\text { selectivity } \\
\text { over } 50 .\end{array}$ & 11 \\
\hline $\begin{array}{l}\text { Graphene reinforced } \\
\text { thin-film polymers }\end{array}$ & $\begin{array}{l}\text { Pores are } \\
\text { formed by } \\
\text { scalable } \\
\text { lithographically } \\
\text { etching. }\end{array}$ & $\begin{array}{l}\text { Selective } \\
\text { polymer layer } \\
\text { needs to be } \\
\text { formed via } \\
\text { sophisticated } \\
\text { interfacial } \\
\text { polymerization. }\end{array}$ & & 22 \\
\hline
\end{tabular}




\section{References}

1. W. Guo, B. Wu, S. Wang, Y. Liu. ACS Nano 2018, 12, 1778-1784.

2. E. Shi, H. Li, L. Yang, J. Hou, Y. Li, L. Li, A. Cao, Y. Fang. Adv. Mater. 2015, 27, $682-688$.

3. A. G. Nasibulin, A. Kaskela, K. Mustonen, A. S. Anisimov, V. Ruiz, S. Kivisto, S. Rackauskas, M. Y. Timmermans, M. Pudas, B. Aitchison, M. Kauppinen, D. P. Brown, O. G. Okhotnikov and E. I. Kauppinen, ACS Nano 2011, 5, 3214-3221.

4. A. C. Ferrari and D. M. Basko, Nat. Nanotech. 2013, 8, 235-246.

5. L. G. Cancado, A. Jorio, E. H. Martins Fereira, F. Stavale, C. A. Achete, R. B. Capaz, M. V. O. Moutinho, A. Lombardo, T. S. Kulmala, A. C. Ferrari, Nano Lett. 2011, 11, 3190-3196.

6. H. W. Kim, H. W. Yoon, S. M. Yoon, B. M. Yoo, B. K. Ajn, Y. H. Cho, H. J. Shin, H. Yang, U. Paik, S. Kwon, Science, 2013, 342, 91-95.

7. W. Ying, J. Cai, K. Zhou, D. Chen, Y. Ying, Y. Guo, X. Kong, Z. Xu, X. Peng, ACS Nano 2018, 12, 5385-5393.

8. F. Zhou, H. N. Tien, W. L. Xu, J.-T. Chen, Q. Liu, E. Hicks, M. Fathizadeh, S. Li, M. Yu, Nat. Commun. 2017, 8, 2107.

9. S. Wang, Y. Wu, N. Zhang, G. He, Q. Xin, X. Wu, H. Wu, X. Cao, M. D. Guiver and Z. Jiang, Energy Environ. Sci., 2016, 9, 3107-3112.

10. Y. Fu, Y.-B. Jiang, D. Dunphy, H. Xiong, E. Coker, S. Chou, H. Zhang, J. M. Vanegas, J. G. Croissant and J. L. Cecchi, Nat. Commun., 2018, 9, 990.

11. G. He, S. Huang, L. F. Villalobos, J. Zhao, M. Mensi, E. Oveisi, M. Rezaei, K. V. 
Agrawal, Energy Environ. Sci. 2019, 12, 3305-3312.

12. T. C. Merkel, H. Lin, X. Wei, R. Baker, J. Membr. Sci. 2010, 359, 126-139.

13. S. Kim, S. H. Han and Y. M. Lee, J. Memb. Sci., 2012, 403-404, 169-178.

14. S. Kim, J. Hou, Y. Wang, R. Ou, G. P. Simon, J. G. Seong, Y. M. Lee and H. Wang, J. Mater. Chem. A, 2018, 6, 7668-7674.

15. N. Du, H. B. Park, G. P. Robertson, M. M. Dal-Cin, T. Visser, L. Scoles, M. D. Guiver, Nat. Mater. 2011, 10, 372-375.

16. T. C. Merkel, H. Lin, X. Wei and R. Baker, J. Memb. Sci., 2010, 359, 126-139.

17. W. Ying, J. Cai, K. Zhou, D. Chen, Y. Ying, Y. Guo, X. Kong, Z. Xu, X. Peng, ACS Nano 2018, 12, 5385-5393.

18. Z. Qiao, S. Zhao, M. Sheng, J. Wang, S. Wang, Z. Wang, C. Zhong, M. D. Guiver, Nat. Mater. 2019, 18, 163-168.

19. K. Xie, Q. Fu, C. Xu, H. Lu, Q. Zhao, R. Curtain, D. Gu, P. A. Webley, G. G. Qiao, Energy Environ. Sci. 2018, 11, 544-550.

20. P. D. Sutrisna, J. Hou, M. Y. Zulkifli, H. Li, Y. Zhang, W. Liang, D. M. D’Alessandro, V. Chen, J. Mater. Chem. A 2018, 6, 918-931.

21. Zhao, J.; He, G.; Huang, S.; Villalobos, L.; Dakhchoune, M.; Bassas, H.; Agrawal, K. Sci. $A d v .2019,5$, eaav1851.

22. Choi, K.; Droudian, A.; Wyss, R. M.; Schlichting, K.; Park, H. G. Sci. Adv. 2018, 4, eaau0476. 